\title{
AN APPROACH FOR HOTEL TYPE SELECTION BASED ON THE SINGLE-VALUED INTUITIONISTIC FUZZY NUMBERS
}

\author{
KARABASEVIC Darjan", POPOVIC Gabrijela², STANUJKIC Dragisa ${ }^{3}$, \\ MAKSIMOVIC Mladjan ${ }^{4}$, SAVA Cipriana ${ }^{5}$ \\ 1 Faculty of Applied Management, Economics and Finance, University Business Academy in Novi Sad (SERBIA) \\ 2 Faculty of Management in Zajecar, Megatrend University in Belgrade (SERBIA) \\ 3 Technical Faculty in Bor, University of Belgrade (SERBIA) \\ 4 Faculty of Applied Management, Economics and Finance, University Business Academy in Novi Sad (SERBIA) \\ 5 Faculty of Tourism and Commercial Management, Christian University "D.Cantemir" Timisoara (ROMANIA) \\ E-mails:darjan.karabasevic@mef.edu.rs,gabrijela.popovic@fmz.edu.rs,dstanujkic@tfbor.ac.rs, \\ mladjan.maksimovic@mef.edu.rs, cipriana.sava@gmail
}

\begin{abstract}
The main objective of this paper is to emphasize the importance of the involving the Multiple-Criteria Decision-Making (MCDM) methods in the process of the selection of the optimal type of hotel for investment. Besides, the application of the Single-Valued Intuitionistic Fuzzy Numbers (SVIFN) is proposed. The applicability of the proposed approach is demonstrated through real case study directed to the selection of the appropriate type of hotel for investment that should be constructed in the Golija Mountain. Three decision-makers estimated five alternative types of hotels relative to the five evaluation criteria. The obtained results are reliable and representative and confirm that introducing of the appropriate multiplecriteria models minimize the possibility of making wrong decisions.
\end{abstract}

Keywords: Multiple-Criteria Decision-Making, Single-Valued Intuitionistic Fuzzy Numbers, Hotel property development, Investment, Selection

JEL: D81

UDC: 005.311.6:[338.488.2:640.4(497.11)

005:519.226

COBISS.SR-ID 277908748 


\section{INTRODUCTION}

Investing in the development of a hotel is similar to investing in any kind of real estate and contains three main phases: development, operation and exit (Younes \& Kett, 2006). The issue that further complicates decisions about investment in this kind of property is question if the investor should invest in a full service hotel, limited service hotel, and apartments or shared ownership. Development of the mentioned types of facilities is followed by different levels of risk and because of that all influential criteria should be appreciated during the decision-making and selection process. The authors proposed different sets of the criteria for the selection of optimal real estate i.e. hotel for investing in. Some of these authors are Zavadskas, Ustinovichius \& Stasiulionis (2004), Migilinskas \& Ustinovichius (2007), Ginevičius \& Zubrecovas (2009). Because decision-making process is relied on the set of criteria that often are conflicting, the Multiple-Criteria Decision-Making (MCDM) methods are suitable for applying in the area of the selection of the suitable type of a hotel for investment.

The MCDM methods are widely used for the facilitation of the decision-making process in different business fields (Popovic et al., 2019; Stojcic et al., 2019; Chatterjee \& Stevic, 2019; Nunic, 2018; Stanujkic \& Karabasevic, 2018; Pamucar et al., 2018; Milosavljevic, Bursaca \& Trickovic, 2018; Veskovic et al., 2018). The good overviews of these methods are given in the papers by Velasquez \& Hester (2013), and Mardani et al. (2015a). During the time, appropriate extensions of the given methods are proposed by introducing the fuzzy sets and some authors performed the systematization of the extended methods (Mardani et al., 2015b; Kahraman, Onar \& Oztaysi, 2015).

In the area of the hotel operating, the MCDM methods are most often used for estimation of the building's energy efficiency (Xu \& Chan, 2013), for the location selection (Krylovas, Zavadskas \& Kosareva, 2016), and accomodation quality estimation (Park, Kim \& Choo, 2014). The selection of the suitable type of hotel for construction is the topic that was not observed enough. The authors give the attention to the selection of the construction projects in general (Ebrahimnejad et al., 2012; Taylan et al., 2014; Gajzler \& Zima, 2017). Popovic, Stanujkic \& Karabasevic (2019) proposed the application of the hybrid model based on the SWARA and WS PLP methods in the case of selection of the appropriate hotel type for construction.

In this paper the evaluation and selection of the appropriate type of hotel for investing in is performed by using an approach based on Single-Valued Intuintionistic Fuzzy Numbers (SVIFN). Three decision-makers (hereinafter marked as $D M \mathrm{~s}$ ) assessed five types of hotels planned for the construction on the Golija mountain (Horwath HTL, 2007) in relation to the selected set of 5 criteria. We emphasize the fact that the main goal of the paper is to point out the advantages and applicability of the SVIFN in the process of estimation and selection of the optimal type of a hotel for investment. With that aim, the rest of the paper is organized as follows: Section 1 presents the Introduction; Section 2 presents the Preliminaries, Section 3 presents Numerical illustration and finally at the end of the manuscript Conclusions are given. 


\section{PRELIMINARIES}

This section considers some basic concepts of Intuitionistic Fuzzy Set (IFS), Intuitionistic Fuzzy Numbers (IFNs) and linguistic variables.

\section{Basic concepts of Intuitionistic Fuzzy Sets}

IFS theory was introduced by Error! Hyperlink reference not valid. (1986). In addition to belonging to a set, proposed in Fuzzy Set (FS) theory, in IFS theory Error! Hyperlink reference not valid. also introduced not belonging to a set. Therefore, an IFS $\tilde{A}$ in $X$ can be defined as follows

$$
\tilde{A}=\left\{\left\langle x, \mu_{A}(x), v_{A}(x)\right\rangle \mid x \in X\right\},
$$

where: $\mu_{A}(x)$ and $v_{A}(x)$ denote the degree of membership and the degree of nonmembership of the element $x$ to the set $A$, respectively; $\mu_{A}: X \rightarrow[0,1]$ and $v_{A}: X \rightarrow[0,1]$; $0 \leq \mu_{A}(x)+v_{A}(x) \leq 1$.

In addition, a very useful parameter, called the degree of indeterminacy $\pi_{A}(x)$ of $x$ to $A$, is defined in the IFSs theory, as follows

$$
\pi_{A}(x)=1-\mu_{A}(x)-v_{A}(x)
$$

under the following condition

$$
\pi_{A}(x) \in[0,1] .
$$

\section{Single-Valued Intuitionistic Fuzzy Numbers}

As with the FS theory, the IFS theory also proposes several shapes of IFNs. The significant shapes are the triangular and trapezoidal ones when the linear membership functions are used, while with the bell-shaped ones the non-linear membership functions are preferred.

In addition to the above-mentioned shapes, the singleton shape can be pointed out as a characteristic one. A singleton IFN $\tilde{A}$, or Single-Valued Intuitionistic Fuzzy Number (IVIFN), $\tilde{A}=\left\langle a, a^{\prime}\right\rangle$, is defined with the membership $\mu_{A}(x)$ and non-membership $v_{A}(x)$ function, respectively, as follows:

$$
\begin{gathered}
\mu(x)=\left\{\begin{array}{cc}
1 & x=a, \\
0 & \text { otherwise, }
\end{array}\right. \\
v(x)= \begin{cases}1 & x=a^{\prime} \\
0 & \text { otherwise, }\end{cases}
\end{gathered}
$$

where: parameter $a$ indicates the most promising value that describes belonging to a set, parameter $a^{\prime}$ indicates the most promising value that describes not-belonging to a set. 
Basic operations on SVIFNs. The operations of addition and multiplication on IFSs were defined by Atanassov (1994). Let $\tilde{A}=\left\langle a, a^{\prime}\right\rangle$ and $\tilde{B}=\left\langle b, b^{\prime}\right\rangle$ be two SVIFNs. Then, the operations of addition and multiplication on SVIFNs are as follows:

$$
\begin{aligned}
& \tilde{A}+\tilde{B}=\left\langle a+b-a b, a^{\prime} b^{\prime}\right\rangle, \\
& \tilde{A} \cdot \tilde{B}=\left\langle a b, a^{\prime}+b^{\prime}-a^{\prime} b^{\prime}\right\rangle .
\end{aligned}
$$

Score function of SVIFNs. Chen and Tan (1994) introduced a Score function to provide a method for comparing IFSs. Let $\tilde{A}=\left\langle a, a^{\prime}\right\rangle$ be a SVIFN. Then, the score $S_{\tilde{A}}$ of $\tilde{A}$ is as follows

$$
S_{\tilde{A}}=a-a^{\prime},
$$

where $S_{\tilde{A}} \in[-1,1]$. shown.

As in the case of IFSs, the Score function can be used to rank the IFNs, as it is previously

Ranking of SVIFSs. For two SVIFNs $\tilde{A}$ and $\tilde{B}$, with scores $S_{A}$ and $S_{B}$, the following condition applies:

$$
\tilde{A}>\tilde{B} \quad \text { if } \quad S_{A}>S_{B}
$$

Intuitionistic Weighted Arithmetic Mean of SVIFNs. Let $\tilde{A}_{j}=\left\langle a_{j}, a_{j}^{\prime}\right\rangle$ be a collection of singletons SVIFNs. Then, the IWAM of singleton IFNs is as follows

$$
\operatorname{IWAM}\left(\tilde{A}_{1}, \tilde{A}_{2}, \ldots, \tilde{A}_{n}\right)=\left(1-\prod_{j=1}^{n}\left(1-a_{j}\right)^{w_{j}}, \prod_{j=1}^{n}\left(a_{j}^{\prime}\right)^{w_{j}}\right)
$$

\section{Intuitionistic Fuzzy Linguistic Variables}

The linguistic variables have been extensively used in order to simplify the use of fuzzy numbers. In this approach a linguistic scale adopted from Stanujkic, Zavadskas, \& Tamošaitiene (2015) is used. The linguistic scale is shown in Table 1.

Table 1: Linguistic variables for expressing satisfaction and dissatisfaction levels

\begin{tabular}{l|c}
\hline Linguistic variable & The corresponding numerical values \\
\hline Completely (C) & 0.995 \\
\hline Very high (VH) & 0.875 \\
\hline High (H) & 0.750 \\
\hline Moderate high (MH) & 0.625 \\
\hline Moderate (M) & 0.500 \\
\hline Moderate low (ML) & 0.375 \\
\hline Low (L) & 0.250 \\
\hline Very Low (VL) & 0.125 \\
\hline Insignificantly Little (IL) & 0.005 \\
\hline
\end{tabular}




\section{NUMERICAL ILLUSTRATION}

In this section, the usage of SVIFNs is demonstrated on a case of the most appropriate hotel type selection on the Golija mountain. A team of three experts (decision-makers) has been formed with the aim of carrying out an evaluation.

At the beginning of the evaluation, the team of experts have defined a set of evaluation criteria. In this case, the team of experts have selected the following criteria: Investment - IN $\left(C_{1}\right)$; Number of units - NU $\left(C_{2}\right)$; Total area - TA $\left(C_{3}\right)$; Price per night - PN $\left(C_{4}\right)$; and Events $\mathrm{EV}\left(C_{5}\right)$. Proposed set of the evaluation criteria will be used to evaluate five types of hotels planned for the construction on the Golija mountain (Horwath HTL, 2007): Destination hotel $A_{1}$; Condotel $-A_{2} ; \mathrm{B}+\mathrm{B}$ Pensions $-A_{3}$; City houses $-A_{4}$; and Chalets $-A_{5}$.

After that, experts evaluated alternatives in relation to selected criteria. In doing so, experts express their level of satisfaction and level of dissatisfaction using the linguistic variables shown in Table 1 , or the numbers from an interval $[0,1]$. The ratings obtained from three experts are shown in Tables 2, 3 and 4.

Table 2: The ratings obtained from the first of the three experts

\begin{tabular}{c|c|c|c|c|c|c|c|c|c|c}
\hline Criteria & \multicolumn{2}{|c|}{$C_{1}$} & \multicolumn{2}{c|}{$C_{2}$} & \multicolumn{2}{c|}{$C_{3}$} & \multicolumn{2}{c|}{$C_{4}$} & \multicolumn{2}{c}{$C_{5}$} \\
\hline Alternatives & $\mu$ & $v$ & $\mu$ & $v$ & $\mu$ & $v$ & $\mu$ & $v$ & $\mu$ & $v$ \\
\hline$A_{1}$ & $\mathrm{M}$ & $\mathrm{L}$ & $\mathrm{H}$ & $\mathrm{VL}$ & $\mathrm{H}$ & $\mathrm{VL}$ & $\mathrm{H}$ & $\mathrm{VL}$ & $\mathrm{M}$ & $\mathrm{IL}$ \\
\hline$A_{2}$ & $\mathrm{MH}$ & $\mathrm{ML}$ & $\mathrm{H}$ & $\mathrm{VL}$ & $\mathrm{VH}$ & $\mathrm{VL}$ & $\mathrm{H}$ & $\mathrm{L}$ & $\mathrm{MH}$ & $\mathrm{VL}$ \\
\hline$A_{3}$ & $\mathrm{M}$ & $\mathrm{VL}$ & $\mathrm{M}$ & $\mathrm{L}$ & $\mathrm{L}$ & $\mathrm{IL}$ & $\mathrm{M}$ & $\mathrm{VL}$ & $\mathrm{MH}$ & $\mathrm{L}$ \\
\hline$A_{4}$ & $\mathrm{M}$ & $\mathrm{VL}$ & $\mathrm{MH}$ & $\mathrm{ML}$ & $\mathrm{MH}$ & $\mathrm{IL}$ & $\mathrm{M}$ & $\mathrm{VL}$ & $\mathrm{M}$ & $\mathrm{IL}$ \\
\hline$A_{5}$ & $\mathrm{~L}$ & $\mathrm{VL}$ & $\mathrm{H}$ & $\mathrm{L}$ & $\mathrm{L}$ & $\mathrm{H}$ & $\mathrm{H}$ & $\mathrm{L}$ & $\mathrm{M}$ & $\mathrm{VL}$ \\
\hline
\end{tabular}

Table 3: The ratings obtained from the second of the three experts

\begin{tabular}{|c|c|c|c|c|c|c|c|c|c|c|}
\hline Criteria & \multicolumn{2}{|c|}{$C_{1}$} & \multicolumn{2}{|c|}{$C_{2}$} & \multicolumn{2}{|c|}{$C_{3}$} & \multicolumn{2}{|c|}{$C_{4}$} & \multicolumn{2}{|c|}{$C_{5}$} \\
\hline Alternatives & $\mu$ & $v$ & $\mu$ & $v$ & $\mu$ & $v$ & $\mu$ & $v$ & $\mu$ & $v$ \\
\hline$A_{1}$ & ML & $\mathrm{L}$ & M & VL & $\mathrm{MH}$ & IL & $\mathrm{M}$ & $\mathrm{L}$ & MH & IL \\
\hline$A_{2}$ & $\mathrm{MH}$ & IL & $\mathrm{H}$ & VL & $\mathrm{H}$ & $\mathrm{L}$ & $\mathrm{H}$ & IL & $\mathrm{H}$ & IL \\
\hline$A_{3}$ & ML & $\mathrm{L}$ & ML & VL & ML & $\mathrm{L}$ & ML & $\mathrm{IL}$ & ML & $\mathrm{L}$ \\
\hline$A_{4}$ & $\mathrm{~L}$ & IL & $\mathrm{MH}$ & VL & $\mathrm{H}$ & IL & $\mathrm{M}$ & IL & $\mathrm{L}$ & IL \\
\hline$A_{5}$ & VL & IL & M & IL & MH & IL & MH & IL & $\mathrm{L}$ & IL \\
\hline
\end{tabular}

Table 4: The ratings obtained from the third of the three experts

\begin{tabular}{c|c|c|c|c|c|c|c|c|c|c}
\hline Criteria & \multicolumn{2}{|c|}{$C_{1}$} & \multicolumn{2}{c|}{$C_{2}$} & \multicolumn{2}{c|}{$C_{3}$} & \multicolumn{2}{c|}{$C_{4}$} & \multicolumn{2}{c}{$C_{5}$} \\
\hline Alternatives & $\mu$ & $v$ & $\mu$ & $v$ & $\mu$ & $v$ & $\mu$ & $v$ & $\mu$ & $v$ \\
\hline$A_{1}$ & ML & VL & MH & IL & MH & L & MH & VL & MH & IL \\
\hline$A_{2}$ & M & L & VH & IL & VH & IL & M & VL & H & IL \\
\hline$A_{3}$ & M & IL & ML & VL & ML & IL & M & IL & M & IL \\
\hline$A_{4}$ & ML & IL & H & IL & H & IL & M & IL & ML & IL \\
\hline$A_{5}$ & L & IL & MH & L & MH & IL & MH & IL & ML & IL \\
\hline
\end{tabular}

In order to be evaluated further, the ratings from Tables 2, 3 and 4 are transformed into numerical values. After that, the group performance ratings are calculated using IWAM operator, i.e. using Eq. (10). During this calculation, it is assumed that all experts have the same significance, that is $1 / K$, which is 0.333 . The group performance ratings are shown in Table 5 . 
Table 5: The group performance ratings

\begin{tabular}{c|c|c|c|c|c}
\hline Weights & 0.25 & 0.21 & 0.18 & 0.20 & 0.15 \\
\hline $\begin{array}{c}\text { Criteria } \\
\text { Alternatives }\end{array}$ & $C_{1}$ & $C_{2}$ & $C_{3}$ & $C_{4}$ & $C_{5}$ \\
\hline$A_{1}$ & $\langle 0.54,0.00\rangle$ & $\langle 0.66,0.12\rangle$ & $\langle 0.66,0.00\rangle$ & $\langle 0.68,0.00\rangle$ & $\langle 0.6,0.00\rangle$ \\
\hline$A_{2}$ & $\langle 0.47,0.00\rangle$ & $\langle 0.66,0.00\rangle$ & $\langle 0.73,0.00\rangle$ & $\langle 0.57,0.00\rangle$ & $\langle 0.47,0.00\rangle$ \\
\hline$A_{3}$ & $\langle 0.34,0.00\rangle$ & $\langle 0.58,0.19\rangle$ & $\langle 0.58,0.00\rangle$ & $\langle 0.54,0.00\rangle$ & $\langle 0.43,0.00\rangle$ \\
\hline$A_{4}$ & $\langle 0.24,0.00\rangle$ & $\langle 0.42,0.00\rangle$ & $\langle 0.47,0.00\rangle$ & $\langle 0.42,0.00\rangle$ & $\langle 0.27,0.00\rangle$ \\
\hline$A_{5}$ & $\langle 0.09,0.00\rangle$ & $\langle 0.36,0.00\rangle$ & $\langle 0.09,0.00\rangle$ & $\langle 0.36,0.00\rangle$ & $\langle 0.20,0.00\rangle$ \\
\hline
\end{tabular}

The criteria weights, shown in Table 5, were determined using PIPRECIA method (Stanujkic et al., 2017).

On the basis of the data from Table 5, the overall performance ratings are also determined using Eq. (10). Then, using Eq. (8), the value of the Score function for each of the considered alternatives was determined.

The overall performance ratings, values of Score function, and ranking order of consideration websites are shown in Table 6.

Table 6: The ranking order of the analyzed websites obtained on the basis of Score function

\begin{tabular}{c|c|c|c}
\hline Alternatives & IWAM & $S_{\mathrm{i}}$ & Rank \\
\hline$A_{1}$ & $<0.63,0.00>$ & 0.316 & 1 \\
\hline$A_{2}$ & $\langle 0.59,0.00>$ & 0.296 & 2 \\
\hline$A_{3}$ & $<0.5,0.00>$ & 0.252 & 3 \\
\hline$A_{4}$ & $<0.37,0.00>$ & 0.187 & 4 \\
\hline$A_{5}$ & $\langle 0.23,0.00>$ & 0.118 & 5 \\
\hline
\end{tabular}

As it can be seen from Table 6 , the alternative $A_{1}$ is the most appropriate one among the considered alternatives.

\section{CONCLUSIONS}

Hotel industry represents an important industry that is often a subject to change. However, what cannot be changed easily, and to a great extent affects the business operations of the hotel, is precisely the type of hotel. Thus, when investing, special attention is given to the selection of the type of hotel for construction. The selection of the suitable type of hotel is usually the result of many analyzes, calculations and market research.

The selection of the suitable type of hotel for construction is the topic that was not observed enough. Therefore, in this paper is proposed one approach for the evaluation and selection of the appropriate type of the hotel for investing based on Single-Valued Intuitionistic Fuzzy Numbers. The applicability of the proposed approach is demonstrated through conducted real case study of the selection of appropriate type of hotel on Golija Mountain.

Conducted numerical example (case study) has shown that proposed approach is adequate when it comes to the selection of type of hotel. Alternative $A_{1}$ - destination hotel is the most appropriate one among the considered alternatives for construction on the Golija Mountain in the present conditions. If it is necessary approach could be easily adjusted with additional criteria of sub-criteria if needed. Also, proposed approach can be successfully applied for 
solving problems in other areas as well. Obtained results confirm that application of the appropriate MCDM based models will minimize possibility of making wrong decisions, especially when it comes to investing.

\section{REFERENCES}

[1] Atanassov, K. T. (1986). Intuitionistic fuzzy sets. Fuzzy sets and Systems, 20(1), pp. 87-96.

[2] Atanassov, K. T. (1994). New operations defined over the intuitionistic fuzzy sets. Fuzzy sets and Systems, 61(2), pp. 137-142.

[3] Chatterjee, P., \& Stević, Ž. (2019). A two-phase fuzzy AHP-fuzzy TOPSIS model for supplier evaluation in manufacturing environment. Operational Research in Engineering Sciences: Theory and Applications, 2(1), pp. 72-90.

[4] Chen, S. M. \& Tan, J. M. (1994). Handling multicriteria fuzzy decision-making problems based on vague set theory. Fuzzy sets and systems, 67(2), pp. 163-172.

[5] Ebrahimnejad, S., Mousavi, S. M., Tavakkoli-Moghaddam, R., Hashemi, H., \& Vahdani, B. (2012). A novel two-phase group decision making approach for construction project selection in a fuzzy environment. Applied Mathematical Modelling, 36(9), pp. 4197-4217.

[6] Gajzler, M., \& Zima, K. (2017). Evaluation of planned construction projects using fuzzy logic. International Journal of Civil Engineering, 15(4), pp. 641-652.

[7] Ginevičius, R., \& Zubrecovas, V. (2009). Selection of the optimal real estate investment project basing on multiple criteria evaluation using stochastic dimensions. Journal of Business Economics and Management, 10(3), pp. 261-270.

[8] Horwath HTL. (2007). Master plan for tourism development on Golija with the business plan. Zagreb: Horwath Consulting (in Serbian).

[9] Kahraman, C., Onar, S. C., \& Oztaysi, B. (2015). Fuzzy multicriteria decision-making: a literature review. International Journal of Computational Intelligence Systems, 8(4), pp. 637-666.

[10] Krylovas, A., Zavadskas, E. K., \& Kosareva, N. (2016). Multiple criteria decision-making KEMIRA-M method for solution of location alternatives. Economic Research-Ekonomska Istraživanja, 29(1), pp. 50-65.

[11] Mardani, A., Jusoh, A., Nor, K., Khalifah, Z., Zakwan, N., \& Valipour, A. (2015a). Multiple criteria decision-making techniques and their applications-a review of the literature from 2000 to 2014. Economic Research-Ekonomska Istraživanja, 28(1), pp. 516-571.

[12] Mardani, A., Jusoh, A., \& Zavadskas, E. K. (2015b). Fuzzy multiple criteria decisionmaking techniques and applications-Two decades review from 1994 to 2014. Expert systems with Applications, 42(8), pp. 4126-4148.

[13] Migilinskas, D., \& Ustinovichius, L. (2007). Normalisation in the selection of construction alternatives. International Journal of Management and Decision Making, 8, pp. 297-313.

[14] Milosavljević, M., Bursaća, M., \& Tričković, G. (2018). Selection of the railroad container terminal in Serbia based on multi criteria decision-making methods. Decision Making: Applications in Management and Engineering, 1(2), pp. 1-15.

[15] Nunić, Z. B. (2018). Evaluation and selection of Manufacturer PVC carpentry using FUCOM-MABAC model. Operational Research in Engineering Sciences: Theory and Applications, 1(1), pp. 13-28.

[16] Pamučar, D., Lukovac, V., Božanić, D., \& Komazec, N. (2018). Multi-criteria FUCOMMAIRCA model for the evaluation of level crossings: case study in the Republic of Serbia. Operational Research in Engineering Sciences: Theory and Applications, 1(1), pp. 108-129. 
[17] Park, D. B., Kim, K. H., \& Choo, H. (2014). The development of quality standards for rural farm accommodations: A case study in South Korea. Journal of Hospitality \& Tourism Research, 41(6), pp. 673-695.

[18] Popovic, G., Stanujkic, D., Brzakovic, M., \& Karabasevic, D. (2019). A multiple-criteria decision-making model for the selection of a hotel location. Land Use Policy, 84, pp. 49-58.

[19] Popovic, G., Stanujkic, D., \& Karabasevic, D. (2019). A framework for the evaluation of hotel property development projects. International Journal of Strategic Property Management, 23(2), pp. 96-107.

[20] Stanujkic, D., Zavadskas, E. K., Karabasevic, D., Smarandache, F., \& Turskis, Z. (2017). The use of Pivot Pair-wise Relative Criteria Importance Assessment method for determining weights of criteria. Romanian Journal of Economic Forecasting, 20(4), pp. 116-133.

[21] Stanujkic, D., Zavadskas, K.E., \& Tamošaitiene, J. (2015). An approach to measuring website quality in the rural tourism industry based on Atanassov intuitionistic fuzzy sets, E+M Ekonomie a Management, 18(4), pp. 461-470.

[22] Stanujkić, D., \& Karabašević, D. (2018). An extension of the WASPAS method for decision-making problems with intuitionistic fuzzy numbers: a case of website evaluation. Operational Research in Engineering Sciences: Theory and Applications, 1(1), pp. 29-39.

[23] Stojčić, M., Zavadskas, E. K., Pamučar, D., Stević, Ž., \& Mardani, A. (2019). Application of MCDM Methods in Sustainability Engineering: A Literature Review 20082018. Symmetry, 11(3), pp. 350.

[24] Taylan, O., Bafail, A. O., Abdulaal, R. M., \& Kabli, M. R. (2014). Construction projects selection and risk assessment by fuzzy AHP and fuzzy TOPSIS methodologies. Applied Soft Computing, 17, p. 105-116.

[25] Velasquez, M., \& Hester, P. T. (2013). An analysis of multi-criteria decision making methods. International Journal of Operations Research, 10(2), pp. 56-66.

[26] Vesković, S., Stević, Ž., Stojić, G., Vasiljević, M., \& Milinković, S. (2018). Evaluation of the railway management model by using a new integrated model DELPHI-SWARAMABAC. Decision Making: Applications in Management and Engineering, 1(2), pp. 34-50.

[27] Xu, P., \& Chan, E. H. W. (2013). ANP model for sustainable Building Energy Efficiency Retrofit (BEER) using Energy Performance Contracting (EPC) for hotel buildings in China. Habitat International, 37, pp. 104-112.

[28] Younes, E. and Kett, R., 2008. Hotel investment risk: what are the chances?. In Handbook of hospitality strategic management (pp. 127-138). Routledge.

[29] Zavadskas E. K., Ustinovichius, L., \& Stasiulionis, A. (2004). Multicriteria valuation of commercial construction projects for investment purposes. Journal of Civil Engineering and Management, 10(2), pp. 151-166.

\section{Article history:}

- Received 25 May 2019

- Accepted 28 Juny 2019 